\title{
The Method of Interactive Reduction of Threat of Isolation in the Contemporary Human Environment
}

\author{
Teresa Musioł and Katarzyna Ujma-Wąsowicz \\ Silesian University of Technology \\ Poland
}

\section{What is the place of a man in an organization?}

In the work process human activity contains rational and irrational elements. Irrational ones are purposes of the activity, whereas ways of achieving them are rational. Irrationality of these purposes lies in constant escalation of improvement a degree of consumerism, i.e. material needs. On the other hand non-material needs are given a role of a derivative, according to modern theories of management in market economy: i.e. first a profit and later the rest. An organization as a group of human individualities cannot constitute a monolith of rational actions. Irrational purposes of an organization are first of all time factors, it means the future determined by consciousness of members of an organization.

The success of an organization is conditioned not only by technical and economic or marketing factors but also by the factors which create favourable conditions for a sense of personal safety of a member of the organization, such as: health, an accident-free job and satisfaction from the activity. In order to make it possible, there must be the atmosphere favourable to basic activities promoting safety. It means that the climate of organizational culture must be a characteristics of a particular organization. Risk and safety are the values which are considered in a particular way in every organization. The attitude of the members of the organization to these values depends on such factors as:

- Kinds and the area of threats and possibility to reduce them;

- The degree of compliance of the conducted business activity with legal requirements, determining the possibility of functioning of the organization in a particular social and legal system;

- The number and seriousness of accidents at work and related material losses of the organization.

The above factors determine the level of culture of safety within the organization, without which functioning in the social environment is not possible (Musiol, 2002).

Every organization as a system, that is a group of elements and relations between them, is subjected to actions of powers of endo- and egzogenic characteristics. In order to realize its purposes, an organization needs to aim at balance between these powers, it means at a state of safety of an organization. The state of organization's safety is understood here as its ability to protect internal values from external threats, however it may be also the vice versa. It is related to a kind of these threats and their attribution in two aspects: objective and 
subjective. Risks existing in an organization are every event or a process undesirable from a point of view of undisturbed system operation. We can't talk about an isolated human or a situation. There is only a relation between a human and the environment - the relation which can be well defined by a word THREAT (Musioł \& Ujma-Wąsowicz, 2007).

With such defining of the term 'threat', any form of disruption of the state of safety within the organization is subjected to assessment and evaluation of measurable and immeasurable threats. They step into the area of "soft organizational culture", which fundamental characteristics is style of management and coordination of activities in the work process, it means orienting the work process towards argumentation, not power. Careful observation of all events inside and outside the organization enables to identify a kind of a threat and to evaluate it correctly. It is very important because the threat may contribute to the organization's success as well as its failure (Musioł, 2007).

The work process, as every process, is subjected to static - dynamic quantification (Musioł \& Ligarski, 2004), where there is specific feedback between technical and economic conditions and a man operating and controlling this process. The information flow, particularly its quality and kind, message codes, the size of a stream and the level of the information flow is an indispensible condition to achieve the balance between a sender and a receiver in the process of communication. The level of balance is determined by the function of the state of communication in its area, i.e. entropy (Fig. 1). It depends mainly on self-consciousness of people who communicate with each other and being together in the communication process. The lack of balance between basic kinds of verbal and non-verbal communication leads to disruptions in exogenous as well as endogenous environment of human life. Therefore, a man in his ontological dimension must all his life broaden the knowledge about ontology of work and ontology of culture and consequently, develop consciousness of such civilization threats as: exploitation, unemployment, famine, devastation of natural environment, violence, terrorism, racism, lack of tolerance, and first of all isolation.

WHAT WE WANT TO SAY
WHAT WE SAY
WHAT ONE HEARS
WHAT ONE LISTENS TO
WHAT ONE UNDERSTANDS ONE REMEMBERS
WHAT WILL BE THE CONSEQUENCE

Figure 1. Graphic representation of communication entropy

\section{What is consciousness?}

The problem of consciousness can be approached from different points of view.

The neurobiologist A. R. Damasio in his book "The Feeling of What Happens: Body and Emotion in the Making of Consciousness" writes: “... the theory of consciousness should not be only the theory describing how the brain turns attention to the image of a particular object. In my opinion, the natural attention on low level precedes consciousness in development, whereas the controlled attention appears after consciousness comes into being. Attention is equally indispensable for consciousness as images. However, it is not sufficient to create consciousness and it is not identical with consciousness. Eventually, the 
theory of consciousness should not be only the theory describing how the brain creates integrated and unified mental scenes, although creating these scenes is an important aspect of consciousness - especially its highest levels. Consciousness does not happen publicly but inside the organism. Nonetheless, it is connected with a number of external symptoms. Those manifestations do not describe an internal process in the same direct way as a sentence expresses a thought but there are some observable signs of presence of consciousness. Relying on what we know about "personal" human brains and what we can observe in human behaviour, we can create three-cornered relationship between:

1. Some external indications, e.g. vigil, emotion, attention or specific behaviour;

2. Corresponding internal manifestations described by the same human being in whom we find the above external indications;

3. Internal manifestations, which we as observers can verify in ourselves, when we are in the circumstances similar to these in which the observed person is found.

This three-cornered relationship entitles us to make considerably motivated conclusions about personal states of a human, on the basis of his external behaviours. Therefore, consciousness is the key to the knowledge about life for good and bad, our first pass to understand famine, desire, sex, tears, laugh, kicks, punches, streams of images called thoughts, feelings, words, history, opinions, music and poetry, happiness and delight. The basic, elementary role of consciousness is making it possible to discern irresistible need for staying alive and development of caring for oneself. However, the most complex and sophisticated task is making it possible to develop care for other people and perfecting the way of life" (Damasio, 1999).

Another approach to the problem of consciousness is represented by the Danish existentialist $S$. Kiergegaard.

In his book "The Sickness Unto Death" he writes that consciousness does not exist as a separate function, having a structure and a location in a brain. It is not anything either internal or external. It is given, so it meets the requirements of a phenomenon. Consciousness is selfknowledge, which decides about an attitude of a human to himself. The more consciousness, the more personality and will. A man who does not have will, doesn't have personality and self-knowledge. Lack of consciousness is always a reason of evil. And in human activity it creates a base for destructive processes in every organized sphere of life, especially in an organization. The human activity in work process without the ergonomic consciousness will be always the reason of destructive activities and it proves the lack of safety consciousness of all work process participant. (Kiergegaard, 1995). Why? His psychological and emotional process determined the satisfaction while capturing needs of self-knowledge through understanding needs of surrounding external world by empathy (Stein, 1988).

And here the following questions appear. How to find relationships between neurobiological, philosophical and behavioural conception of consciousness and selfconsciousness and can these relationships be evaluated in a clear way? This is a difficult problem because a human as an individual is a phenomenon, in whom internal conceptual area is not always compatible with external perceptual area, conditioned by a particular situation (Fig. 2) (Musioł, 2003).

The imperative of recognition for behaviours consciousness are exogenous and endogenous factors that change human work and therefore the state changes for safety of the environment. Continuing the question it may be worth to ask how large is the evil, which is the result of consciousness missing in every society that the safety is an element of the 
cultures in their psychological dimension. It is also everyday and basic obligation of the ethical duty not only in relation to oneself but also to other people. So it is necessary to change in the thinking process basing on the "Newton's paradigm", which is going into the thinking basing on the "paradigm of the imagination".

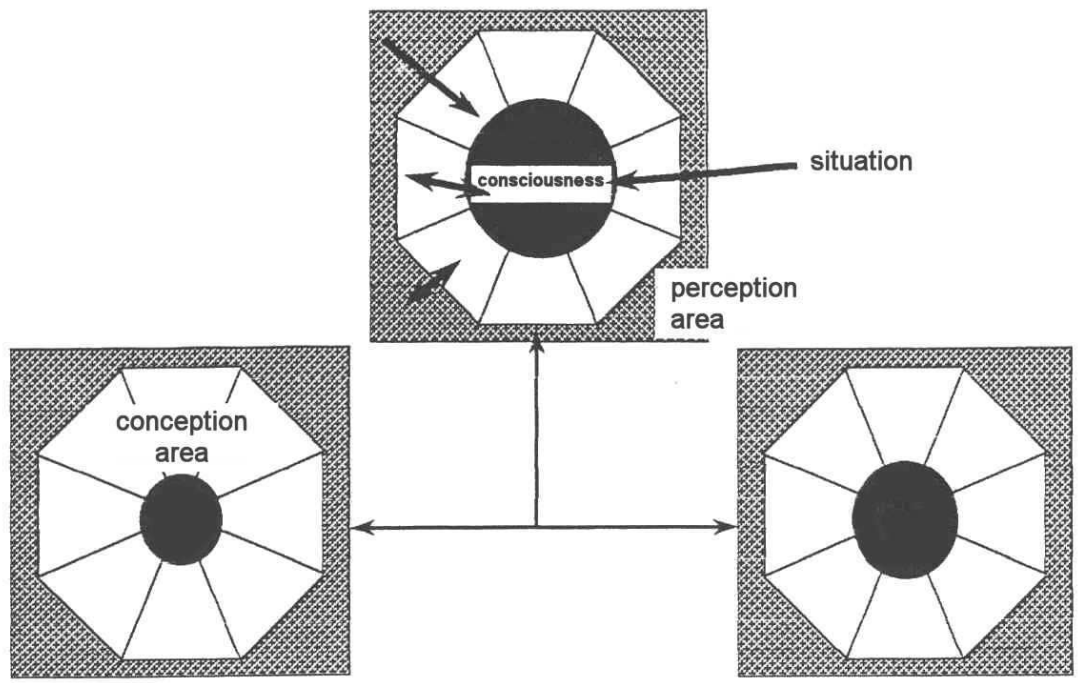

Figure 2. The relations between the consciousness and the behaviour

And there is a question: why? The answer this question is: because a human as anique individual is a phenomenon, in which the psychophysical and emotional processes determine the satisfaction of the need of capturing a self-knowledge about itself and surrounding external world by category as like empathy, in other words of understanding situation of another human. (Stein, 1998)

Because the area of the culture represents the collection of skilled phenomena it means that the culture is not transmitted throughout the genes activity but throughout the learning process. The learning may be the result of the imitation (benchmarking) or the active training. As it was mentioned above the essence of learning process of the ergonomics cognitive is the growth of ergonomic consciousness. It means capturing the theoretical and practical information about manners of the behaviour in many kinds of situations related to many different phenomena. A result of a lack of these of information is a conflict focus between the conceptional and perceptual assessment of the given situation and it is the primitive threats. These threats have an exogenous character and they are the reason of destructive behaviours.

In the age of globalization and computerization, communication between people without meetings and verbal conversations is becoming a standard. Young people prefer to shut themselves away in the world of the Internet and computer games rather than to go for example for a walk and play with friends in the open space (often considering such activities as a waste of time). Case studies of reasons of suicides, increase in aggression or becoming depressed among young people indicate necessity of monitoring threats caused by these facts. Regarding this, the following thesis was proposed in the elaboration: "Isolation caused by coexistence with information technology devices of different kinds is a threat for psychological environment of not only an individual human, but also any social and professional groups". 
The purpose of research, which result is this report, was an answer for a question if there is a problem of isolation caused by work with a computer and if a person subjected to 'the research' is aware of it. Furthermore, if such isolation exists, is its reduction in Polish society possible by active recreation and practicing sport in groups?

In the industrial period an assembly line was a place of creation economic value of an organization. Today interpersonal communication with transmission of information about different values but first of all about global trade offer attracting consumer's attention is becoming such a place (Musiol, 2007).

\section{Case Study - how to make an evaluation of the state of consciousness? (Musioł, 2005)}

The essence of the process of learning the ergonomics cognitive is the growth of the ergonomics consciousness degree related to the environment of human life and work. For this purpose the knowledge about all threats around us and methods of their identification helps us first of all. It is influenced by the ergonomic cognitive, which stands (treats)a human as a subject in his environment and it is natural cognitive act performed in the relation to the environment.

Correct identification of threats in environment of our life, according to their attribution, is a necessary condition of preventive actions as well as actions correcting results of these threats for an individual as well as the rest of society. Monitoring of the state of consciousness concerning the reasons but also results of threats seems purposeful in aspect of ergonomic knowledge.

During a period from June 2004 to January 2005 after an ergonomics lecture research of individual assessment of a state of consciousness within a group of 265 persons was carried out. Research was carried out during classes of part-time studies and post-graduate studies. All questionnaires in number of 265 items were verified by the author. The results of the verification were :

- 61 questionnaires were filled in incorrectly;

- 26 persons filling in questionnaires were unemployed;

- 81 employed persons had secondary education (s.ed.);

- 97 employed persons had higher education (h.ed.);

- the range of age of participants was: from 21 to 60 years;

For meritoric analysis of answers there were chosen at random:

- 45 questionnaires of employed participants with secondary education (s.ed.)

- 45 questionnaires of employed participants with higher education (h.ed.).

Both groups are in the age range from 25 to 40 years, so in a period of intensive gaining of work experience.

Research was conducted by means of a questionnaire of individual assessment of ergonomic consciousness. The essence of the questionnaire was a following description of a case:

"A housewife is having an accident after having used an electric bread slicer. The result is cutting a fingertip of an index finger of a right hand. Give reasons of this accident in aspect of ergonomic requirements. Choose an answer separately for every reason, giving one mark in a scale 1-3 (1-the lowest mark, 3-the highest mark)."

The questionnaire was constructed in matrix system in the following way: vertically there were 7 reasons of an accident, horizontally there were 3 states of consciousness concerning these reasons. 
Horizontally -3 states of consciousness concerning reasons of an accident

- I am sure;

- $\quad$ it seems to me;

- I must have more information.

Vertically -7 reasons of an accident

- incorrect work area;

- lack of protective equipment;

- technical reasons;

- lack of knowledge about threats;

- excessive static-dynamic load;

- $\quad$ incorrect material environment;

- $\quad$ psychophysical state.

Meritoric analysis of answers was conducted by means of indexes of attribution of ergonomic consciousness as arithmetical average and weighted average of a given attribute. Attribute of a reason of an accident $\overline{\mathrm{c}}_{\mathrm{a}_{\mathrm{r}}}$ and attribute of a state of an ergonomic consciousness $\bar{c}_{a_{c}}$ were calculated by means of arithmetical average sum of marks from 45 measures chosen at random.

The attributes of a state of consciousness during a choice of reasons of an accident were calculated by means of weighted average $\bar{c}_{w_{r_{1}-7}}$ i $\bar{c}_{w_{c_{1-3}}}(1)(2)$.

$$
\bar{c}_{w r_{j}}=\frac{1}{i} \sum_{i=1}^{3} \bar{c}_{w_{c_{i}}}
$$

where:

$\bar{c}_{w_{r_{j}}} \quad$ - weighted average for one reason of an accident, from 1 to 7

$\bar{c}_{w_{c_{i}}} \quad$ - arithmetical averages of three states of consciousness concerning one reason of an accident

$i=3$ - maximum number of points for assessment of one reason

$$
\bar{c}_{w_{c_{i}}}=\frac{1}{j} \sum_{j=1}^{7} \bar{c}_{a_{r_{j}}}
$$

where:

$\bar{c}_{w_{c_{i}}} \quad$ - weighted average for one state of consciousness from 1 to 3

$\bar{c}_{a_{r_{j}}} \quad$ - arithmetical averages for seven reasons of an accident

$j=7 \quad$ - maximum number of points for assessment of one state of consciousness

Table 1 refers to answers of participants with secondary education and Table 2 refers to answers of participants with higher education. 


\begin{tabular}{|c|c|c|c|c|c|}
\hline & $\begin{array}{l}\text { Reason of accident } \\
\overline{\mathrm{c}}_{\mathrm{a}_{\mathrm{r}_{1-7}}}\end{array}$ & $\begin{array}{l}\text { I am sure } \\
\qquad \overline{\mathrm{c}}_{\mathrm{a}_{\mathrm{c}_{1}}}\end{array}$ & $\begin{array}{c}\text { It seems to } \\
\text { me } \\
\bar{c}_{\mathrm{a}_{\mathrm{c}_{2}}}\end{array}$ & $\begin{array}{c}\text { I must have more } \\
\text { information } \\
\overline{\mathrm{c}}_{\mathrm{a}_{\mathrm{c}_{3}}}\end{array}$ & $\overline{\mathrm{c}}_{\mathrm{w}_{\mathrm{r}_{1-7}}}$ \\
\hline$\overline{\mathrm{c}}_{\mathrm{a}_{\mathrm{r}_{1}}}$ & Incorrect work area & 1,24 & 0,64 & 0,40 & 0,76 \\
\hline$\overline{\mathrm{c}}_{\mathrm{a}_{\mathrm{r}_{2}}}$ & Lack of protective equipment & 1,44 & 0,40 & 0,33 & 0,72 \\
\hline$\overline{\mathrm{c}}_{\mathrm{a}_{\mathrm{r}_{3}}}$ & Technical reasons & 0,60 & 0,78 & 0,47 & 0,61 \\
\hline$\overline{\mathrm{c}_{\mathrm{a}_{4}}}$ & $\begin{array}{l}\text { Lack of knowledge about } \\
\text { threats }\end{array}$ & 1,71 & 0,67 & 0,07 & 0,81 \\
\hline$\overline{\mathrm{c}_{\mathrm{a}_{5}}}$ & $\begin{array}{l}\text { Excessive static-dynamic } \\
\text { load }\end{array}$ & 0,62 & 0,73 & 0,35 & 0,57 \\
\hline$\overline{\mathrm{c}}_{\mathrm{a}_{\mathrm{r}_{6}}}$ & $\begin{array}{l}\text { Incorrect material } \\
\text { environment }\end{array}$ & 0,55 & 0,73 & 0,62 & 0,63 \\
\hline$\overline{\mathrm{c}_{\mathrm{a}_{\mathrm{F}_{7}}}}$ & Psychophysical state & 1,84 & 1,09 & 0,44 & 1,12 \\
\hline & $\overline{\mathrm{c}}_{\mathrm{w}_{\mathrm{c}_{1-3}}}$ & 0,38 & 0,24 & 0,13 & \\
\hline
\end{tabular}

Table 1. Value of indexes of attribution of ergonomic consciousness - persons with secondary education (s.ed.)

\begin{tabular}{|c|c|c|c|c|c|}
\hline & $\begin{array}{l}\text { Reason of accident } \\
\qquad \overline{\mathrm{c}}_{\mathrm{a}_{\mathrm{r}_{1-7}}}\end{array}$ & $\begin{array}{c}\text { I am sure } \\
\qquad \overline{\mathrm{c}}_{\mathrm{a}_{\mathrm{c}_{1}}}\end{array}$ & $\begin{array}{l}\text { It seems to } \\
\text { me } \\
\overline{\mathrm{c}}_{\mathrm{a}_{\mathrm{c}_{2}}}\end{array}$ & $\begin{array}{c}\text { I must have more } \\
\text { information } \\
\overline{\mathrm{c}}_{\mathrm{a}_{\mathrm{c}_{3}}}\end{array}$ & $\overline{\mathrm{c}}_{\mathrm{w}_{\mathrm{r}_{1-7}}}$ \\
\hline$\overline{\mathrm{c}}_{\mathrm{a}_{\mathrm{r}_{1}}}$ & Incorrect work area & 0,51 & 0,51 & 1,00 & 0,67 \\
\hline$\overline{\mathrm{c}}_{\mathrm{a}_{\mathrm{r}_{2}}}$ & Lack of protective equipment & 1,20 & 0,42 & 0,31 & 0,64 \\
\hline$\overline{\mathrm{c}}_{\mathrm{a}_{\mathrm{r}_{3}}}$ & Technical reasons & 0,66 & 0,60 & 0,78 & 0,68 \\
\hline$\overline{\mathrm{c}}_{\mathrm{a}_{\mathrm{r}_{4}}}$ & $\begin{array}{l}\text { Lack of knowledge about } \\
\text { threats }\end{array}$ & 1,70 & 0,60 & 0,13 & 0,81 \\
\hline$\overline{\mathrm{c}}_{\mathrm{a}_{\mathrm{r}_{5}}}$ & $\begin{array}{l}\text { Excessive static-dynamic } \\
\text { load }\end{array}$ & 0,48 & 0,44 & 0,67 & 0,53 \\
\hline$\overline{\mathrm{c}}_{\mathrm{a}_{\mathrm{r}_{6}}}$ & $\begin{array}{l}\begin{array}{l}\text { Incorrect material } \\
\text { environment }\end{array} \\
\end{array}$ & 0,40 & 0,26 & 0,95 & 0,54 \\
\hline$\overline{\mathrm{c}}_{\mathrm{a}_{\mathrm{r}_{7}}}$ & Psychophysical state & 1,29 & 0,64 & 0,47 & 0,80 \\
\hline & $\overline{\mathrm{c}}_{\mathrm{w}_{\mathrm{c}_{1-3}}}$ & 0,30 & 0,16 & 0,20 & \\
\hline
\end{tabular}

Table 2. Value of indexes of attribution of ergonomic consciousness- persons with higher education (h.ed.) 
Graphs 3 and 4 show graphic representation of research results.

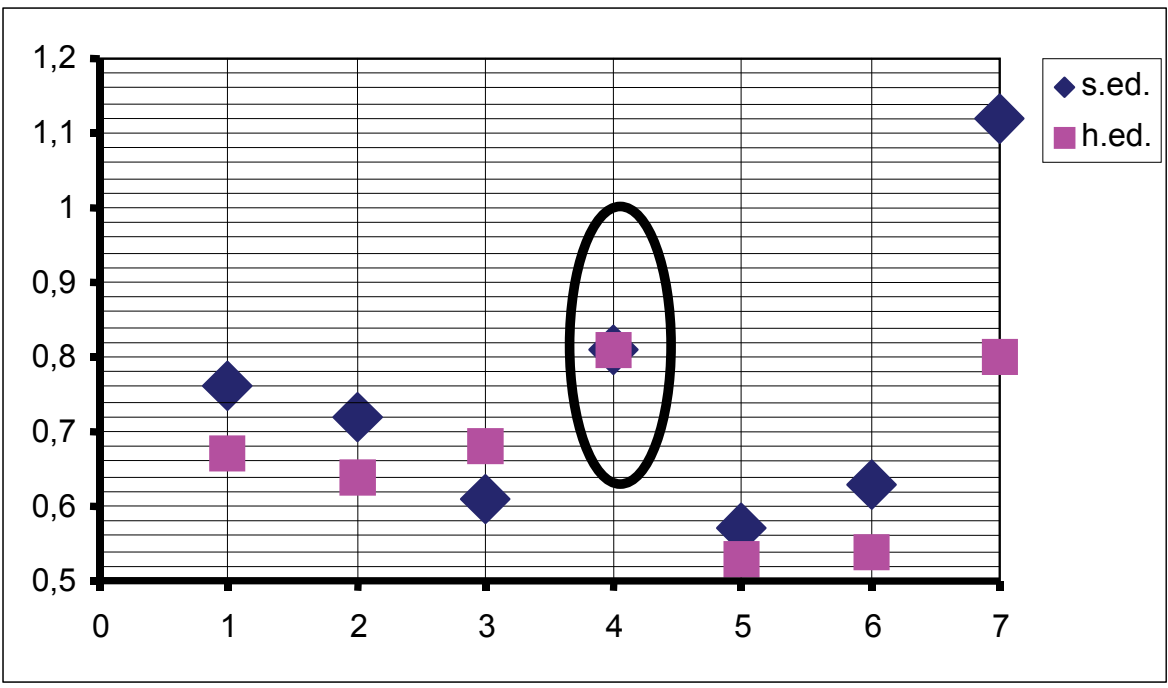

Figure 3. Graphic representation of indexes of attribution of ergonomic consciousness in configuration reason -states

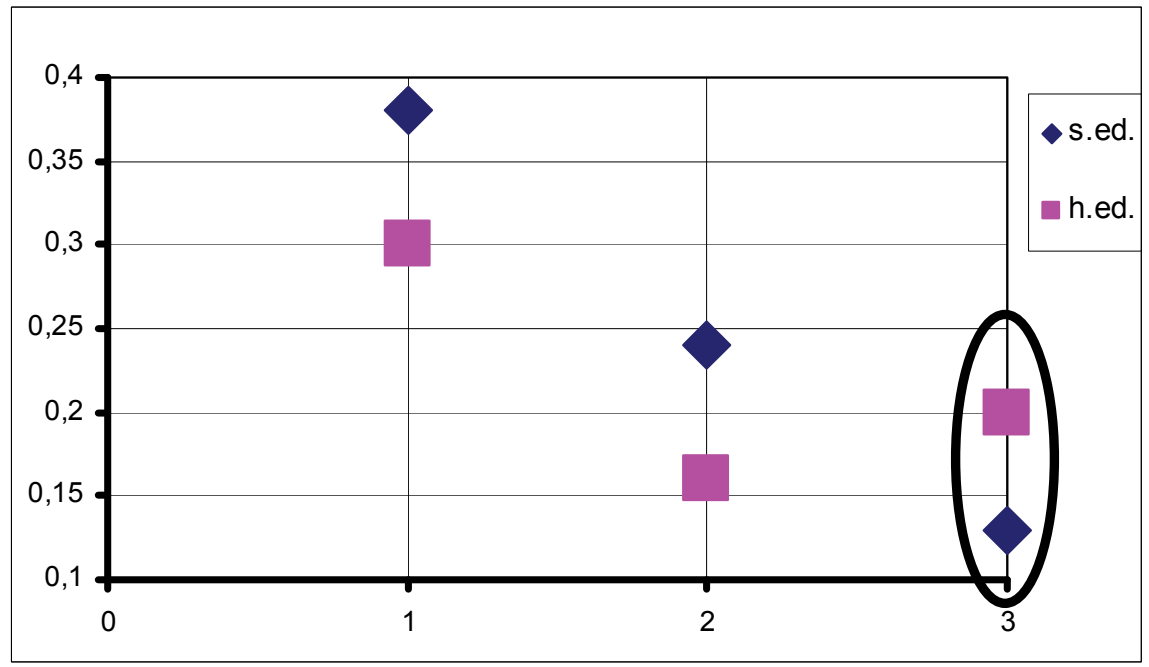

Figure 4. Graphic representation of indexes of attribution of ergonomic consciousness in configuration state - reasons

While analyzing the results the conclusions are following:

- Analysis of research results shows that the lack of knowledge about threats regardless of a level of education is a basic reason of an accident. Index 0,81 for persons with 
higher education as well as for these with secondary education confirms this conclusion.

- Interpreting a kind of states of ergonomic consciousness depending on a reason of an accident (graph 2) one must notice that persons with higher education must have more information about a threat to make a decision than persons with secondary education (index 0,20 and 0,13)

- Persons with secondary education as well as persons with higher education indicate a psychophysical state as a main reason of an accident - index 1,84 and 1,29. In case of participants with higher education this index is consirably high (lack of immunity to stress).

\section{Can the lack of face-to-face communication be a threat?}

As it was mentioned before (point 1.), entropy of the state of communication is communication space depends first of all on its kind, message codes, intensity of information flow between a sender and a receiver, as it was presented in Fig. 5

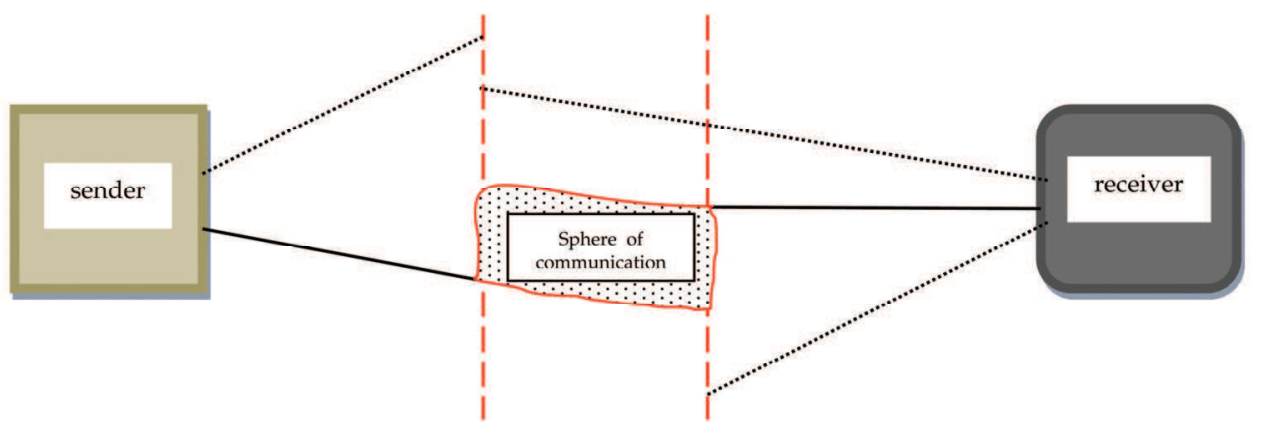

Figure 5. Ideogram of communication process

It is important if the communication is verbal or non-verbal. Functioning of the rational brain is manifested by words, whereas emotions are manifested by non-verbal behaviours. Actually, when words of a person do not correspond with pitch of the voice or other non-verbal signals, not what is said but how it is said indicates his or her real emotions. In the research on communication it was found that $90 \%$ or more of conveyed emotions are sent by non-verbal canals. Messages such as anxiety heard in someone's voice, irritation indicated by fast gestures are almost always received unconsciously, without putting particular attention to a character of a message, with a silent assumption that real content enables good or bad reception of such messages. It proves that directing emotions towards a useful purpose is a masterly skill. Regardless of the fact, if it is represented by constant controlling of impulses or temporary putting off fulfilments for later, mood should be controlled in such a way, so that it simplified our life, and didn't make it more difficult. (Goleman, 1997).

Apart from energy, we also need empathy to communicate. The term 'empathy' was used for the first time in the 20s by the American psychologist E. B. Tichener (Goleman, 1997). This meaning differs slightly from the Greek word emathea "emphasizing" adopted earlier, previously used by theorists of aesthetics to describe the ability to perceive subjective sensations of another individual. According to Ticherer's theory, empathy 
derives from a certain kind of physical imitating of worry or depression of another person, which would semantically differ from the term "sympathy" meaning what we feel towards another person, not experiencing to any extent the same feeling which she or he does. Empathy grows from self-consciousness - the more we are open on our own emotions, the more and better we perceive emotions of other people. Edith Stein in her doctoral thesis "About Empathy Problem" proved that empathy is a phenomenological category because a human is an individuality and a phenomenon in his physiologicalpsychological and emotional dimension (Stein, 1988). Some empathy researchers, e.g. Martin Hoffman (Goleman, 1997) formulate a hypothesis that apart from direct relation between empathy and altruism in personal relationships, empathy, it means putting oneself on the place of another person, induces us to obey some moral rules and observing the natural development of empathy from the early childhood to adolescence. Empathy underlies different aspects of evaluation and moral activities. One of such aspects is empathic anger, which John S. Mill (Goleman, 1997) describes as a natural feeling of retaliation triggered off by intellect and sympathy related to injustice, which hurts us because it hurts others. Mill described this feeling as "guard of justice". Another case in which empathy leads to undertaking moral action is a situation when an outside observer protects a victim. The research proves that the more empathy the observer feels towards the victim, the higher is the probability of his intervention. The is also evidence proving that the level of empathy can tinge our moral evaluations (Goleman, 1997).Summing up, some people while feeling empathy must make particular (dependent on a situation) effort meaning identifying with emotional effort of other people and experiencing their emotions. Their emotional intelligence happens to be insufficient in some situations. Thus, the escape into the state of isolation with one-sided communication, related to anonymity.

\section{What is the isolation and can it be a threat?}

Isolation is a basic risk in the area of communication in process of every kind of work. Isolation, as it is defined by Norbert Sillamy is a protective mechanism which aims at weakening perception by breaking it away from a context and its emotional basis'. It means that we deal here with emotional effort with a different degree of intensity, which depending on results of human actions, will have a sign 'plus' or 'minus'. According to Ruben Gallego a bad system of organization, no matter what it concerns, dooms a human to isolation of any kind The author states that isolation is misfortune and he even claims that every kind of isolation is a curse. It's difficult to disagree with this because a man is a social being and contrary to appearances emotional effort in communication with another person is essential, such as dynamic effort is indispensable for keeping correct figure. Isolation should not be confused with loneliness, particularly chosen one, because isolation is also a result of rational actions undertaken by natural, social and family environment on an isolated person (Musioł \& Ujma-Wąsowicz, 2007).

The World Health Organization (WHO) examined young people in 41 countries in Europe and Northern America. In Poland five and half thousand teenagers, aged 11, 13 and 15, were subjected to examination. The children were asked how they feel, what they eat, if they have friends, how their relationships in the family look like, if they like school, drink alcohol, smoke cigarettes and take drugs. Generally, the received answers indicate that Polish teenagers do not differ considerably from their peers from other countries, taking into 
account the threat of pathologies. However, there are some symptoms which may worry. It turns out that a Polish teenager uses stimulants more frequently than young people from other countries. What also worries is the fact that Polish teenagers have less friends and instead of meeting them they prefer playing computer games. The reasons for this phenomenon are sought in mentality and the style of bringing up in a Polish family - being mistrustful of the outer world, i.e. isolating oneself and on the other hand lack of a sufficient number of educational programmes improving self-esteem, developing communication skills and work in a group (Karwowska, 2008).

Another worth mentioning reason for isolation is professional burnout. More and more people suffer from psychosomatic diseases. There is an increasing number of strokes, heart attacks because of overwork, exhaustion, stress and too many duties at work. The syndrome of burnout may strike down everyone but first of all it applies to people who are very ambitious and extremely involved in their work. They are usually people with low selfesteem whose opinion about themselves is dependent on opinion of others. Also perfectionists who feel responsible for everything and want to do everything the best are prone to burnout. There are few employees who have courage to assure their employers that this problem does not apply to them - mainly because they are afraid to lose their job.

Ian Harvey, an independent English journalist is a great supporter of digital technology. He talks about his passion of discovering intelligent gadgets. He is fascinated that every day some novelty enters his everyday life. He is fully conscious that the borderline between his job, fun and family life is fading away. However, he claims that his digital likings are as important as a proverbial cup of morning tea.

Cyberspace - the topic which arouses emotions and controversies. We all live in the real world, which is a symbol of the truth and tangibility. Cyberspace can move us to the virtual world, which is a personification of subjectivism.

In the recent years in the world dominated by Virtual Reality (VR) or similar technologies, the attempts of connecting the virtual reality Immersed Virtual Environment (IVE) and the real world - Augmented Reality (AR) are becoming more and more popular. These technologies are present in the areas of:

- interactive games: Motion capture system - "Half-Life2", Mixed Reality MR "AquaGauntlet";

- film: Motion capture system - "Shrek", MR-Space Odyssey - "Matrix", Seeing Through, Inside Out - "Power Rangers";

- advertising;

- $\quad$ trade: Clear and Present Car;

- tourism: Archeoguide, Vilars Augmented Reality, Seeing Through, Inside Out;

- military forces: GRIDS, BARS, Landwarrior, SignPost - Mobile AR Navigation System (Ujma - Wąsowicz \& Gil, 2005).

Cyberspace can be treated as a response to existence of so called mental reception of space. The mental model of space ruled by three types of processes: Enactive Mentality (enables navigation in space), Iconic Mentality (the ability of identification and comparison of mental images and objects in the real world) and Symbolic Mentality (the ability of abstract thinking) allows to create relationships with external environment, remember and find information. Supporters of cyberspace recognise as a drawback a fact that mental reception of space is available only for a single user and the received information is not only a subject to interpretation but also when it is not used and not 
updated, it is deleted. In the contemporary world of cyberspace available via the Internet, chat-rooms, online public spaces these drawbacks do not exist. They are vibrant with human activity and thanks to imagination supported by technology they have become the space of social interaction, taking different forms. An example of such environment is the domain MUD (Multi Users Domain) called Active World. This world has got hundreds of thousands of users called avatars and a similar number of virtual objects. It functions in a form of real communities with their authorities, ordinary citizens, public and private spaces and even politics. In this world a user can exchange views and is offered different ways of spending free time. Everyone can become a citizen of the domain, the only restriction is access to the Internet.

Another form of using cyberspace are so called colaboratories, which are used as a tool for exchanging experiences by professionals specialising in different fields and which are becoming better and better functioning work centres. Interaction of their users is realised mostly via the Internet. Different forms of cooperation are possible: from asynchronous of email type to synchronous of MUD type. One of factors determining the quality and comfort of cooperation is the user interface, evolving from a graphic to multimodal form. The future cooperation can be imagined as meetings of avatars in a selected cybernetic space (Zalewski, 2007).

Threat created as a result of computerization of every sphere of life - also free time, is first of all isolation of personal space. A man is assigned to NIPs, PINs, kodes, so he is identified by numbers. With help of his fingers he communicates with another person in the cybersphere, more and more controlled by other suitable and unsuitable people.

A man, who selectively receives information (limit of amount of information received per second), is not able to receive and process all information he would like to. Selecting requires decisions, i.e. a psychological act, and performing it requires a meaningful emotional effort. An examined man wants to be on his own and he thinks that he can't deal with this effort, and by some thought abbreviations he reduces not so much emotional, but rather intellectual effort. This is a simple way for limiting dialogue with another man, justifying pseudo individuality and negating group work. According to this, a man transmits more and receives less information. He starts to create his internal world, which characteristics obstructs reception of reality. It's simply better to dream than accept 'real' facts (are there any others?). It is a danger leading to all kinds of psychic disorders, because it influences lack of self-acceptance and in consequence to self-destruction in every form. All the more so because very often life in virtual reality deflates self-criticism and there follows subjective favourisation.

It is worth emphasizing that the problem does not lie in development of digital technology, it is quite the opposite. The possibilities to use it in order to obtain information, keep in touch with family and friends, navigate in the area or document memories are all benefits of the $21^{\text {st }}$ century. The problem is that for many people the digital world replaces a friend, deprives them of their free time, limits independent thinking or even deteriorates their functioning in the society. In such circumstances it is easy to imagine a situation in which people on a large scale close in their virtual worlds and isolated from reality lead digital life. 


\section{The method of measurement and evaluation of the threat of isolation caused by computer among Polish students and school teenagers.}

The measurement of a level of isolation was carried out with sociometric measure type 'Rating Scale Questionnaire' (Charlton, 2002), constructed according to the following rules.

The measure contained:

- 10 open questions, a respondent was to answer them by choosing only one option,

- 5 possible answers for

- each of 10 questions,

- which were assessed in the

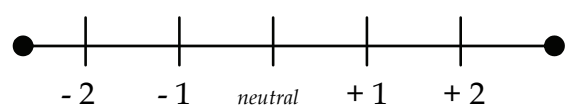

- $\quad$ scale from -2 to +2

- $\quad$ the sixth answer - other comments - which was assigned to a proper scale;

- information gaps, such as age, course mode, date of measurement.

The interpretation of results of measurement of isolation was carried out by assessing every chosen answer for 10 questions in the scale from -2 to +2 .

The questions included such areas as:

- Ways of spending free time the most frequently and the most willingly;

- Amount and quality of free time spent in front of a computer monitor;

- Consciousness of risks related to work with a computer or with other;

- Active recreation and participation in team games as a method of reducing risks related to life in cyberspace.;

The presentation of results of isolation measurement lied in confirming or negating isolation during work with a computer in free time, coming out of a difference of positive $\left(\mathrm{P}_{+}\right)$and negative $\left(\mathrm{P}_{-}\right)$points in the examined sample and. The answers described in the scale as 'neutral' $\left(\mathrm{P}_{\mathrm{N}}\right)$ are considered as 'standard' behavior and are not taken into account . Commenting on positive answers would be necessary if the difference between $\left(\mathrm{P}_{+}\right)$and $\left(\mathrm{P}_{-}\right)$ accured to be "negative". The answers described in the questionnaire as positive represented the methods of reducing the threat of isolation. First of all they included active recreation, participation in team games and social meetings in a group.

\subsection{The first phase of research - students (Musioł \& Ujma-Wąsowicz, 2007).}

Three hundred twelve students of full-time and extension courses were subjected to research. The measurement of isolation was taken during semester classes (thanks to this students had direct contact with the researchers) in the period from 3rd to 27th January 2007. The students represented three faculties of the Silesian University of Technology: Faculty of Organization and Management, Faculty of Architecture and Faculty of Mechanical Engineering as well as Silesian College of Economics and Administration in Bytom (Table 3)

\begin{tabular}{|l|l|l|l|l|}
\hline A1 & Examined sample & $\begin{array}{l}\text { Full-time course } \\
\text { not working }\end{array}$ & Aged 19-25 & 110 questionnaires \\
\hline B1 & Comparative sample & $\begin{array}{l}\text { Extension course } \\
\text { working }\end{array}$ & Aged 19-33 & 110 questionnaires \\
\hline
\end{tabular}

Table 3. The kind of the sample accepted for measurement of isolation caused by using computers in free time.

Results of measurement of a level of isolation among students are presented in Table 4 . 


\begin{tabular}{|c|c|c|}
\hline \multicolumn{3}{|c|}{ Scale of Questions $-2,-1$, neutral, $+1,+2$} \\
\hline \multicolumn{3}{|c|}{ A 1 Full time course, not working } \\
\hline \multirow[b]{2}{*}{$\frac{\mathbf{P}_{\mathrm{A} 1 \_}}{\text {number of negative points }}$} & -2 & -1 \\
\hline & $\begin{array}{c}\text { number of answers } \\
176 \times(-2)=-352\end{array}$ & $\begin{array}{c}\text { number of answers } \\
289 \times(-1)=-289\end{array}$ \\
\hline $\begin{array}{c}\mathbf{P}_{\mathrm{NA} 1} \\
\text { number of neutral points }\end{array}$ & \multicolumn{2}{|c|}{ number of answers } \\
\hline \multirow{2}{*}{$\begin{array}{c}\mathbf{P}_{\mathrm{A} 1+} \\
\text { number of positive points }\end{array}$} & +1 & +2 \\
\hline & $\begin{array}{c}\text { number of answers } \\
205 \times(+1)=+205\end{array}$ & $\begin{array}{c}\text { number of answers } \\
168 \times(+2)=+336\end{array}$ \\
\hline \multicolumn{3}{|c|}{ B 1 Extension course, working } \\
\hline \multirow[b]{2}{*}{$\frac{\mathbf{P}_{\mathbf{B} 1_{-}}}{\text {number of negative points }}$} & -2 & -1 \\
\hline & $\begin{array}{c}\text { number of answers } \\
161 \times(-2)=-322\end{array}$ & $\begin{array}{c}\text { number of answers } \\
269 \times(-1)=-269\end{array}$ \\
\hline $\begin{array}{c}\mathbf{P}_{\mathrm{NB} 1} \\
\text { number of neutral points }\end{array}$ & \multicolumn{2}{|c|}{ number of answers $304=$ neutral } \\
\hline \multirow{2}{*}{$\begin{array}{c}\mathbf{P}_{\mathbf{B} 1+} \\
\text { number of positive points }\end{array}$} & +1 & +2 \\
\hline & $\begin{array}{c}\text { number of answers } \\
237 \times(+1)=+237\end{array}$ & $\begin{array}{c}\text { number of answers } \\
145 \times(+2)=+290\end{array}$ \\
\hline
\end{tabular}

Table 4. Results of measurement of a level of isolation among students caused by using computers in free time

\section{Interpretation of results:}

Level of isolation $\Delta p_{i}$ was calculated as a difference between a number of points from answers to questions contained in positive scale and a number of points from answers to questions contained in negative scale in relation to: full-time course $\mathbf{A 1}$ - examined sample according to formula (3) (Fig. 6) and extension course B1 - comparative sample according to formula (4) (Fig. 7).

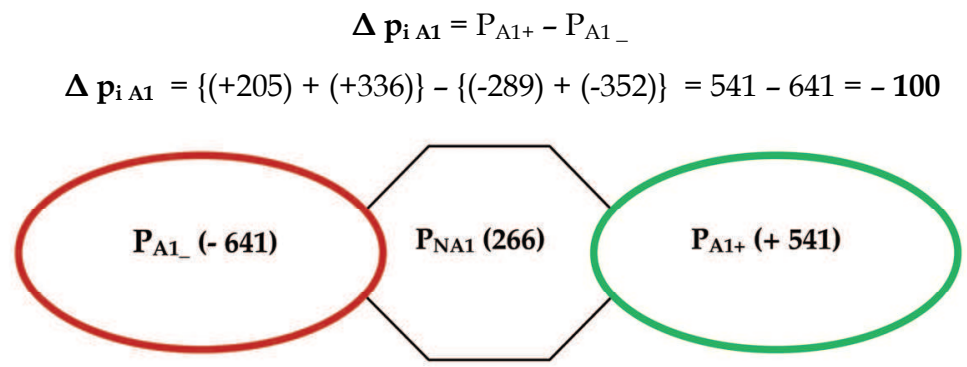

Figure 6. Graphic presentation of the results for full-time course, not working students (A1)

where:

$\Delta \mathrm{p}_{\mathrm{i} \text { A1 }} \quad$ - level of isolation for full-time course, not working students,

$\mathrm{P}_{\mathrm{A} 1+}=\mathrm{P}_{\mathrm{A} 1(+1)}+\mathrm{P}_{\mathrm{A} 1(+2)}$ - summary number of positive points from answers.

$\mathrm{P}_{\mathrm{A} 1-}=\mathrm{P}_{\mathrm{A} 1(-1)}+\mathrm{P}_{\mathrm{A} 1(-2)}-$ summary number of negative points from answers

$\mathrm{P}_{\mathrm{NA1}}-$ number of neutral points

$$
\Delta p_{i \mathbf{B} 1}=\mathrm{P}_{\mathrm{B} 1+}-\mathrm{P}_{\mathrm{B} 1}
$$




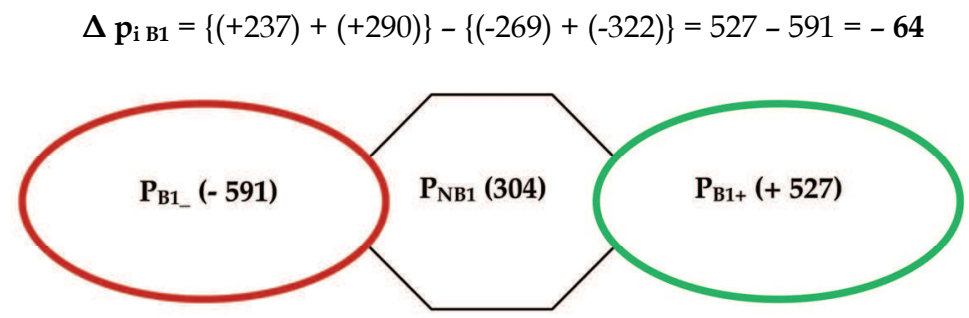

Figure 7. Graphic presentation of the results for working students (B1)

where:

$\Delta \mathrm{p}_{\mathrm{i} \text { B1 }} \quad$ - level of isolation for extension, working students,

$\mathrm{P}_{\mathrm{B} 1+}=\mathrm{P}_{\mathrm{B} 1(+1)}+\mathrm{P}_{\mathrm{B} 1(+2)}$ - summary number of positive points from answers.

$\mathrm{P}_{\mathrm{B} 1_{-}}=\mathrm{P}_{\mathrm{B} 1(-1)}+\mathrm{P}_{\mathrm{B} 1(-2)}$ - summary number of negative points from answers

$P_{\mathrm{NB1}}$ - number of neutral points

Summary:

looking at the above data we come to a conclusion that the level of isolation of full-time students $\Delta p_{\mathrm{i} A 1}=-100$ is higher than the level of isolation of extension students $\Delta \mathrm{p}_{\mathrm{B} 1}=-64$. While analyzing the reasons of isolation, number of points for answers in the negative scale and in the positive scale of full-time and extension students were taken into account. The conclusions are following:

1. The full-time students are not as aware of risk of isolation as the extension students;

2. The full-time students prefer active recreation and team games to a larger extent than the extension students

3. The extension students are more aware of risks caused by work with a computer and they can reduce them better than full-time students For this reason they are in favor of family and social contacts ;

4. The research confirmed the thesis that users of the computers are not aware of this risk. However, instinctively they feel that active recreation and team games are the methods which help not only to relax but also to reduce the effect of isolation.

\subsection{Second phase of research - school teenagers (Ujma-Wąsowicz \& Musioł 2008).}

In June 2008 the research including two phases was conducted. The subject of the research were school teenagers aged from 15 to 19 . The young people attend three middle schools and two secondary schools in Gliwice. The teenagers subjected to the research attend 3 sport classes and 5 general education classes (Table 5).

\begin{tabular}{|c|l|c|}
\hline Age & \multicolumn{1}{|c|}{ Sports activity } & $\begin{array}{c}\text { Number of } \\
\text { questionnaires }\end{array}$ \\
\hline \multirow{3}{*}{$15-19$} & $\begin{array}{l}\text { Young people practising sport in a sport } \\
\text { class or a sport club }\end{array}$ & 135 \\
\cline { 2 - 3 } & $\begin{array}{l}\text { Young people not practicing any sport } \\
\text { discipline }\end{array}$ & 89 \\
\hline & TOTAL & 224 \\
\hline
\end{tabular}

Table 5. The structure of the sample accepted for measurement of isolation among school teenagers caused by using computers in free time 
Thirty-five questionnaires were completed incorrectly. From the remaining 190 questionnaires 136 were chosen according to the following rules:

For the sample A2 representing young people practising sport in a sport class or a sport club 68 questionnaires were chosen at random out of 121 correctly completed questionnaires and for the sample B2 representing young people not practicing any sport discipline all 68 correctly completed questionnaires were accepted.

\begin{tabular}{|l|l|l|l|l|}
\hline A2 & Examined sample & $\begin{array}{l}\text { Young people } \\
\text { practising sport in a } \\
\text { sport class or a sport } \\
\text { club }\end{array}$ & Aged 15 - 19 & 110 questionnaires \\
\cline { 3 - 5 } B2 & Comparative sample & $\begin{array}{l}\text { Young people not } \\
\text { practicing any sport } \\
\text { discipline }\end{array}$ & 110 questionnaires \\
\hline
\end{tabular}

Table 6 . The kind of the sample accepted for measurement of isolation caused by caused by computer and digital devices in free time

Results of measurement of a level of isolation among school teenagers are presented in Table 7.

\begin{tabular}{|c|c|c|}
\hline \multicolumn{3}{|c|}{ Scale of Questions $-2,-1$, neutral, $+1,+2$} \\
\hline A 2 Young people practis & g sport in a sport cla & or a sport club \\
\hline \multirow[b]{2}{*}{$\frac{\mathbf{P}_{\mathrm{A} 2}}{\text { number of negative points }}$} & -2 & -1 \\
\hline & $\begin{array}{c}\text { number of answers } \\
40 \times(-2)=-80\end{array}$ & $\begin{array}{c}\text { number of answers } \\
54 \times(-1)=-54\end{array}$ \\
\hline $\begin{array}{c}\mathbf{P}_{\mathrm{NA} 2} \\
\text { number of neutral points }\end{array}$ & \multicolumn{2}{|c|}{ number of answers $126=$ neutral } \\
\hline \multirow{2}{*}{$\frac{\mathbf{P}_{\mathbf{A} 2+}}{\text { number of positive points }}$} & +1 & +2 \\
\hline & $\begin{array}{c}\text { number of answers } \\
51 \times(+1)=+51\end{array}$ & $\begin{array}{c}\text { number of answers } \\
143 \times(+2)=+286\end{array}$ \\
\hline \multicolumn{3}{|c|}{ B 2 Young people not practising any sport discipline } \\
\hline \multirow[b]{2}{*}{$\frac{\mathbf{P}_{\mathbf{B} 2}}{\text { number of negative points }}$} & -2 & -1 \\
\hline & $\begin{array}{c}\text { number of answers } \\
43 \times(-2)=-86\end{array}$ & $\begin{array}{c}\text { number of answers } \\
74 \times(-1)=-74\end{array}$ \\
\hline $\begin{array}{c}\mathbf{P}_{\mathrm{NB} 2} \\
\text { number of neutral points }\end{array}$ & \multicolumn{2}{|c|}{ number of answers $304=$ neutral } \\
\hline \multirow{2}{*}{$\begin{array}{c}\mathbf{P}_{\mathbf{B} 2+} \\
\text { number of positive points }\end{array}$} & +1 & +2 \\
\hline & $\begin{array}{c}\text { number of answers } \\
66 \times(+1)=+66 \\
\end{array}$ & $\begin{array}{c}\text { number of answers } \\
88 \times(+2)=+\mathbf{1 7 6}\end{array}$ \\
\hline
\end{tabular}

Table 7. Results of measurement of a level of isolation among school teenagers caused by computer and digital devices in free time

Interpretation of results:

Level of isolation $\Delta p_{i}$ was calculated using the same rule as in the first measurement a difference between a number of points from answers to questions contained in positive scale and a number of points from answers to questions contained in negative scale in relation to young people practising sport in a sport class or a sport club: A2 - examined sample 
according to formula (5) (Fig. 8) and young people not practising any sport discipline B2 comparative sample according to formula (6) (Fig. 9).

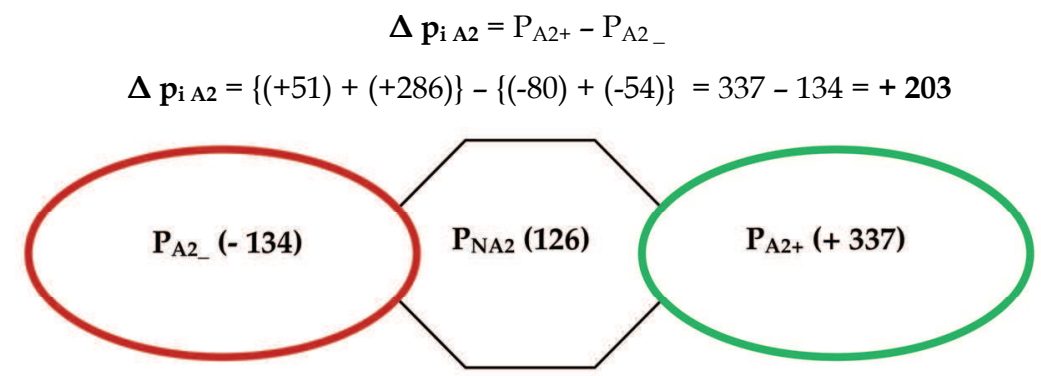

Figure 8. Graphic presentation of the results for school teenagers practising sport in a sport class or a sport club

where:

$\Delta \mathrm{p}_{\mathrm{i} \text { A2 }}$ - level of isolation for school teenagers practising sport in a sport class or a sport club

$\mathrm{P}_{\mathrm{A} 2+}=\mathrm{P}_{\mathrm{A} 2(+1)}+\mathrm{P}_{\mathrm{A} 2(+2)}$ - summary number of positive points from answers

$\mathrm{P}_{\mathrm{A} 2-}=\mathrm{P}_{\mathrm{A} 2(-1)}+\mathrm{P}_{\mathrm{A} 2(-2)}$ - summary number of negative points from answers

$\mathrm{P}_{\mathrm{NA} 2}-$ number of neutral points.

$$
\Delta \mathrm{p}_{\mathrm{iB} 2}=\mathrm{P}_{\mathrm{B} 2+}-\mathrm{P}_{\mathrm{B} 2}
$$

$$
\Delta \mathrm{p}_{\text {і В2 }}=\{(+66)+(+176)\}-\{(-86)+(-74)\}=242-160=+82
$$

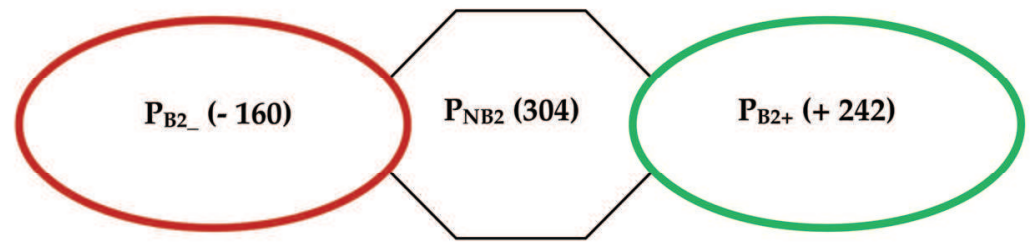

Figure 9. Graphic presentation of the results for school teenagers not practising any sport discipline

where:

$\Delta \mathrm{p}_{\mathrm{i} \text { B2 }} \quad$ - level of isolation for, school teenagers not practising any sport discipline

$\mathrm{P}_{\mathrm{B} 2+}=\mathrm{P}_{\mathrm{B} 2(+1)}+\mathrm{P}_{\mathrm{B} 2(+2)}$ - summary number of positive points from answers

$\mathrm{P}_{\mathrm{B} 2}=\mathrm{P}_{\mathrm{B} 2(-1)}+\mathrm{P}_{\mathrm{B} 2(-2)}$ - summary number of negative points from answers

$\mathrm{P}_{\mathrm{NB} 2}$ - number of neutral points.

Summary:

Looking at the above data we come to a conclusion that isolation among school teenagers was not identified.

While analyzing the reasons of isolation the conclusions are following:

1. Young people practising sport value the possibility of active recreation in a group more than young people who do not practise any sport discipline 
2. Young people practising and not practising sport are unconscious of threats caused by isolation while using a computer and other mobile digital devices. However, in a natural way they intuitively avoid the mentioned dangers reducing them to a smaller or greater degree by group or individual sports activity .

3. For the teenagers who train sport is the most interesting form of spending free time, whereas such a form is perceived as marginal by young people who do not practise sport.

4. In spite of the fact that isolation was not affirmed among school children, the difference of the way of spending free time by teenagers who practise sport and those who do not train was observed. The hypothesis is formulated that the differences result from behavioural consciousness formed during the pedagogical process.

\section{Can the development of outdoor sports contribute to reduction of the threat of isolation?}

In the 90s the research was conducted in the European counties, which revealed that in Poland (like in other counties of Eastern Europe) on average $15 \%$ of adult society regularly practices sport. This phenomenon is amazing, especially in comparison to Western Europe, where this proportion reaches almost 70 \% (Ujma-Wąsowicz, 2007). Since then not much has changed in Poland and a lot of circumstances indicate that the forthcoming future will look similarly.

It is easy to observe that the tendency of sports absence among adult people does not only remain on the same level but increases. Two factors create favorable conditions for deepening these incorrect habits: on the one hand spending long hours in front of a computer monitor by children and teenagers, in perspective adult people, and on the other hand the shortage of commonly available sports infrastructure taking advantage of the technical potential of $21^{\text {st }}$ century and expectations of users. That is why it seems that "environment sport" should offer young people a new and attractive formula of spending free time by means of commonly accessible and safe infrastructure, adjusted to the needs of varied users. Otherwise, the process of lack of interest in active recreation among currently young people and adults in future will be deepened.

Outdoor sport and recreation areas are a considerable percentage of public and semi-public spaces in Polish towns and cities. The serious problem connected with these previously well-kept and today degraded areas e.g. school sports areas and also sports facilities previously belonging to dynamically developing sports clubs, started in the period of our country's political transformation. The related changes caused among others such effects as lack of institutional interest of local authorities in the problem of renovation of sports areas or giving up supporting such complexes by their previous owners e.g. mines or steelworks. Another condition that was an encouragement to begin the research is absence of the disabled in outdoor sports life The disabled are often perceived as the people of the second category. The mentality of able-bodied people does not allow such persons to function normally. These people are not aware that the disabled have the same needs and aspirations as the rest of the society, however their ability to realize them is limited. They do not expect from the society sympathy but support and partnership in aiming at normal functioning in all spheres of life, also in realizing their sports aspirations (Ujma-Wąsowicz, 2007) 


\subsection{Urban, physical and mental health and social behaviors context}

In Poland, particularly in post-industrial towns and cities, the process of degradation of existing sports areas, constituting the considerable percentage of outdoor areas in towns is intensifying. On the other hand, there is a shortage of commonly accessible sport and recreation areas, equipped with suitable infrastructure, i.e. complying with the $21^{\text {st }}$ century standards and, which is the most important, situated in the proximity of the place of residence that encourages different age groups to everyday, spontaneous, active recreation. The existing outdoor sport areas in cities, easily accessible and affordable, such as football pitches by school or housing estates, are in most cases neglected and developed in old-fashioned way. By contrast, the possibility of using attractively organized outdoor sport areas is connected with the necessity of travelling and often fees. They are mostly commercial facilities. The additional problem in Polish cities is lack of commonly accessible sports infrastructure, adjusted to the expectations of the disabled, giving them opportunity to practice sports which are popular among them.

The changes worth aiming at in the context of open sports areas should be understood as:

- realization of the city spatial policy related to balanced development principles;

- restoration of city landscape advantages;

- $\quad$ enliving city public spaces;

- making sports areas available to a broader social group like the disabled or the ones not interested in traditional sports;

- $\quad$ creating new workplaces for everyday supervision and equipment care.

In the era of globalization the characteristic of labour processes is first of all fast information flow. It is based primarily on mobile cybernetic technologies and quality and efficiency of communicating of different cultures in all the world. Therefore, the cyberspace area leads to the future, simultaneously quantifying the past. The side effect of these processes are all kinds of civilization diseases and the syndrome of burnout. To maintain a balance between professional and personal life it is good to invest time in physical, emotional and spiritual development. It can be realized by participation in active practicing uninstitutioned sport, which is a factor reducing health risks. In the same time the awareness of ergonomics and safety of an individual as well as a team is being increased.

Taking into consideration this sphere of human life enables to influence the development of such personality features as:

- physical condition;

- internal motivation to work on oneself;

- resistance to stress;

- $\quad$ ability to work in a group and to solve problems.

On the other hand, the quality of social behaviors of city inhabitants is permanently worsening, particularly of young people, which results in the phenomenon of isolation, aggression and becoming addicted. One of the reasons of such behaviors is lack of alternative forms of spending free time, adequate to the needs of the contemporary man.

To what extend practicing amateur outdoor sport influences our personality?

- it shapes the abilities of spontaneous team work organization;

- it enables organization of active spending free time according to individual needs without necessary "top-down" timetables;

- it creates favorable conditions for integration and co-participation of the disabled in outdoor sports life;

- $\quad$ participation in non-toxic competition. (Ujma-Wąsowicz, 2007b) 


\section{The method of measurement and evaluation of the reduction of isolation among Polish school teenagers}

Considering the specifics of the undertaken problem, it was assumed that the young people were potential external clients of the future facilities. Accordingly, the tools of Total Quality Mangement (TQM) were applied. In order to obtain information which enables to describe the examined reality, by means of number indexes of a single phenomenon as well as showing its specifics, sociological standarized and non-standarized techniques are used for example: a survey form, a questionnaire or an free interview (Bonstingl, 1999). In the presented research non-standarized techniques, i.e. a questionnaire having characteristics of a free interview was applied, constructed on the basis of the authors' set of issues.

The purpose of the research was to diagnose the attitude of young people to pro-sport behaviours in everyday life and then to describe the directions of transformations of existing sports areas in a Polish city (Ujma-Wąsowicz \& Musioł, 2008).

The questionnaire was constructed according to the following principles.

The young people were asked to present their attitude to 5 issues $\left(\mathrm{I}_{\mathrm{i}}\right)$ :

$\mathrm{I}_{1}$ - attitude to television sports programmers;

$\mathrm{I}_{2}$ - the types of facilities that should be built in the surroundings;

$\mathrm{I}_{3}$ - frequency of practicing outdoor sports;

$\mathrm{I}_{4}$ - a way of practicing sport (sports class, sports club);

$\mathrm{I}_{5}$ - the attitude to Physical Education lessons at school.

Each issue was given 3 options of choice $\left(C_{j}\right)$ :

$\mathrm{C}_{1}$ - the first one negated the sense of sport existence;

$\mathrm{C}_{2}$ - the second one described it as an important element of human life;

$\mathrm{C}_{3}$ - the third one described sport as the greatest enjoyment in life.

The respondents were to choose one option $C_{j}$, which obtained 1 point.

The analysis of the results was carried out according to the following formula (7):

$$
P_{i}=\frac{I_{i} C_{j}}{R}
$$

where:

$P_{i}$ - point value of a chosen option $C_{j}$ of a particular issue, where $i=1-5$;

$I_{i}-$ a number of responses for an issue, where $i=1-5$;

$C_{j}-1$ point for the chosen option, where $j=1-3$;

$R$ - number or verified questionnaires; $R=125$.

The results of the research are presented in Table 8 .

\begin{tabular}{|c|c|c|c|}
\hline \multirow{2}{*}{$\begin{array}{c}\text { Point value } \\
P_{\mathrm{i}(1-5)}\end{array}$} & $\mathrm{C}_{1}$ & $\mathrm{C}_{2}$ & $\mathrm{C}_{3}$ \\
\cline { 2 - 4 } & $\mathbf{0 , 0 4}$ & $\mathbf{0 , 8 3}$ & $\mathbf{0 , 1 3}$ \\
\hline $\mathrm{P}_{1}$ & $\mathbf{0 , 1 5}$ & $\mathbf{0 , 3 0}$ & $\mathbf{0 , 5 5}$ \\
\hline $\mathrm{P}_{2}$ & $\mathbf{0 , 0 2}$ & $\mathbf{0 , 8 0}$ & $\mathbf{0 , 1 8}$ \\
\hline $\mathrm{P}_{3}$ & $\mathbf{0 , 4 8}$ & $\mathbf{0 , 0 8}$ & $\mathbf{0 , 4 4}$ \\
\hline $\mathrm{P}_{4}$ & $\mathbf{0 , 1 4}$ & $\mathbf{0 , 6 0}$ & $\mathbf{0 , 2 6}$ \\
\hline $\mathrm{P}_{5}$ & &
\end{tabular}

Table 8. Determining the proportion of teenagers to individual issues $P_{i}$ 
Then point values for the chosen option $\mathrm{C}_{\mathrm{j}}$ were summed up, determining tendencies of pro-sport behaviours (8)

$$
T_{j}=\sum_{i=1}^{5} P_{\mathrm{i}}
$$

where:

$T_{j}$ - point value of the tendency for the option $C_{j}$, where $j=1-3$

$\mathrm{P}_{1}, \mathrm{P}_{2}, \mathrm{P}_{3}, \mathrm{P}_{4}, \mathrm{P}_{5}$ - point values of issues for the chosen option $\mathrm{C}_{\mathrm{j}}$

The is presented in Table 9.

\begin{tabular}{|c|c|c|}
\hline \multicolumn{3}{|c|}{ Point value of the tendency $\mathrm{T}_{\mathrm{j}}$ of pro-sport behaviors' } \\
\hline $\mathrm{T}_{1}$ & $\mathrm{~T}_{2}$ & $\mathrm{~T}_{3}$ \\
\hline $\mathbf{0 , 8 3}$ & $\mathbf{2 , 6 1}$ & $\mathbf{1 , 5 6}$ \\
\hline
\end{tabular}

Table 9. Determining the tendency of everyday pro-sport behaviours of young people $T_{j}$

Summary:

The value $T_{2}=2,60$ indicates that active recreation is an essential element of a young man's life, proving its quality. In spite of long hours spent in front of a computer monitor young people instinctively feel that sport is the method for reduction of isolation, improving physical condition and enjoying time in a group.

\section{Programmes and implementations referring to outdoor sports (Ujma- Wąsowicz \& Musioł, 2008)}

The state of possessed knowledge enables the authors to present examples of programmes intended for popularization of outdoor amateur sport in Poland and abroad as well as modern solutions of outdoor sports areas in urbanized spaces.

The programmes: "A Pitch Nearby" building multifuntional sports pitches commonly accessible to children and teenagers and "Orlik 2012", a very new one are realized in Poland by the Ministry of Sport and Tourism of the Republic of Poland (the difference between them lies in the method of funding). The analysis of these programmes shows that the driving force behind these activities is the good will of investors submitting offers for building complexes of this type. It means that single implementations are realized in new locations in the country, which are not subjected to system activities in the city and district scale.

An extremely interesting foreign example is Millenium Programme "Changing Places" presented at Royal Society of Arts in London in March 1995. The programme is destined for landscape regeneration of 21 sites degradated by industry in England and Wales. The primary principle of "Changing Places" is framing directions of changes on the basis of cooperation of many authorities, particularly local ones (government and non-governmental organizations and the private sector). The programme in every location covers several hectares of land and involves unurbanized areas.

In Poland in urbanized areas the illustration of modern solutions can be "Krakowski Square" in Gliwice, the city where the Silesian University of Technology is located. In 2000 in the centre of the city the multifuntional outdoor complex, covering $800 \mathrm{~m}^{2}$ was built. The 
area belongs to the local government's assets and till 1990s it had been undeveloped and neglected. The implemented project is the place willingly visited by the inhabitants. It comprises varied funtional zones, such as a square with a scene and a stand destined for organizing different kinds of events e.g. every year the street basketball competition is organized here, in which on average 80 teams, mostly from the Silesia, participate (a), a skatepark (b), an alley with a playground for small children (c) and a fountain. Also additional facilities like public toilets, benches and a bus stop, were skillfully integrated into the project (Photo 1).
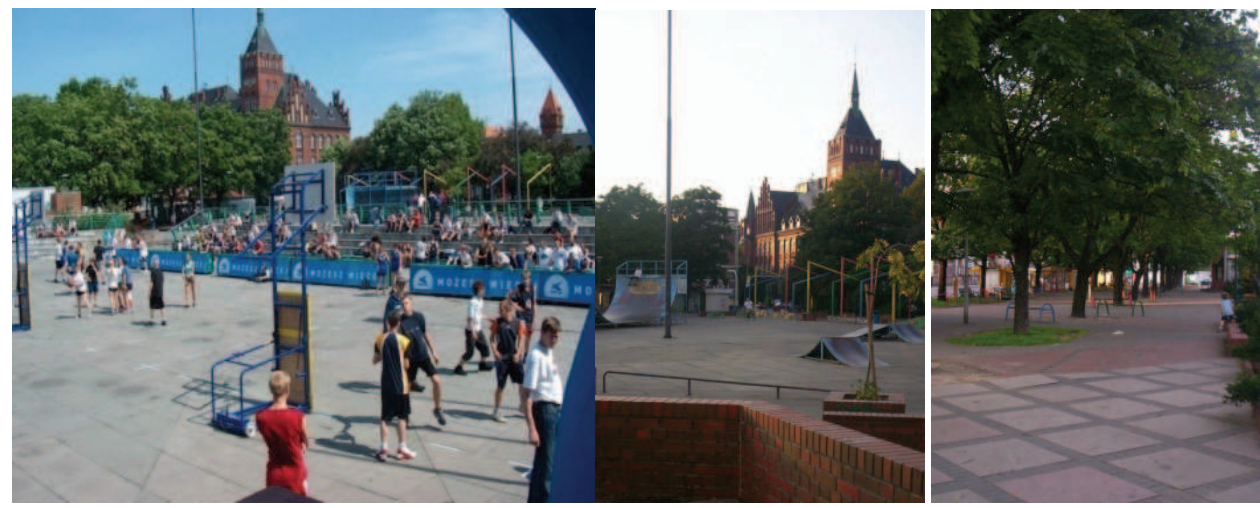

Photo 1. Krakowski Square, Gliwice, Poland (a, b, c)

Another sport and recreation area, having some features of a city square is "Westblaak Skatepark" in Rotterdam in the Netherlands, the project implemented in 2005. It was built in the centre of the city, on a former street. The area is a very popular place. It gathers great numbers of sportsmen and spectators because of its localization and the function it fulfils .

\section{The threat of isolation in a selected professional group}

The professional group of architects was selected for evaluation of the threat of isolation. Presently, designing facilities destined for interactive reduction of the threat of isolation requires application of different kinds of system IT tools. Thus, there is a feedback human computer and consequently, all results of disruption of this relation. One of secondary effects of this relation is the threat of isolation.

The work of architect - creating the space for a man, requires spatial imagination, knowledge and experience. The architect must coordinate four basic elements: the function of the designed area and its form (aesthetics), construction and economically justified costs of the investment. It means that taking into account such extensive spectrum of issues, only professionals, at least theoretically, should undertake architectural designing. Beginning from submitting an offer for performing a design, through proposing solutions, carrying out a construction and detailed design and finishing with building a facility and putting it into operation, an architect's activity is a subject to constant verification, on side of an investor as well as a user. From their point of view the subject of evaluation are:

- functionality of the whole facility;

- $\quad$ adapting the created space to its limitations; 
- guaranteeing its biological and psychological comfort among others, by an appropriate selection of microclimatic conditions, lighting, colours;

- form and aesthetics of the whole facility;

- the way in which a designer communicates and informs about proposed solutions in other words striving to understand expectations of a user and skilful justifying designing decisions).

According to G. Schmitt, our architectural space will develop in three basic trends: Pure Physical Architecture - space conditioned culturally or by specifics of existing, external conditions; Virtual Architecrure - in many respects alternative to physical architecture, understood as virtual environment used for development of social activity and "Bit and Bricks"Architecture - physical structure of buildings is enriched with electronic tools, which create a new environment - monitored, controlled and protected by computers (Zalewski, 2007).

The possibility of creation the virtual world with a real user would make it possible to create a user-friendly space and also to improve communication of a designer with an investor. In this case a designer would be still treated, as it is now, as the only creator of a particular place.

Previous recognition of demand related to potential users, scenarios of behaviour of a larger number of people in a particular situation has fundamental meaning for the correct solution of building's functions. Introducing such tools to work of architect as a programme which recognises designing errors, which make free moving of a man in a designed space difficult, would fulfil a role of "a reviewer" of an architectural functional conception. The possibility of 3D designing with participation of virtual, moving users - "avatars" - 3D models, created on the basis of ergonomic research would be extremely useful.

However, there is another available, although not common, option of designing based on using augmented reality as a basic tool for better communication of an architect, an investor and a user. Software developed on this basis can enable active participation of a recipient in the process of facility creation. Systems of AR or IVR type allow a user to have an impression of being in a designed space, matching VR projection to real user's movements. The well-known software solution of this type is JCAD-VR, developed by a group of scientists from the University Strathclyde in Glasgow. A model of a designed building can be freely scaled, according to users' needs (Fig. 10) (Ujma-Wąsowicz \& Gil, 2005).

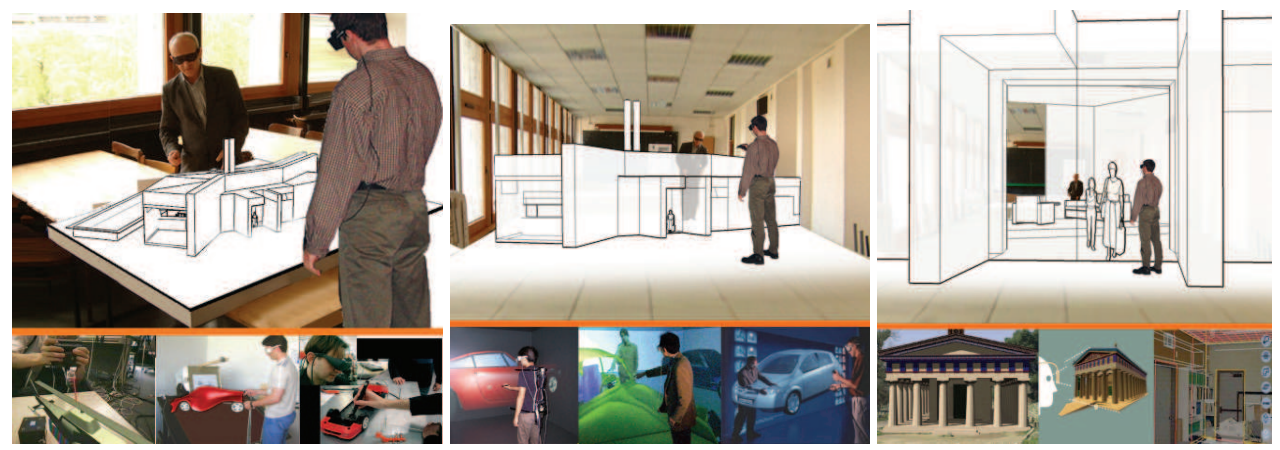

Figure 10. Augmented reality: the possibilities of scaling and "emerging" of a user in a facility with examples of similar solutions from other spheres of human life 
Digital space supports physical environment not only by its constant control and customization. It enables for example, by means of the idea of programmable structure of a building called Hyperbody, to change a shape of this environment and its information content in real time. Such a space is an active structure, controlled by data flow, which changes a shape, volume and information content in real time. A user is not only an observer of the skin - coating, but he is emerged in it. He can "manage" it - alter it using Internet data or doing it from the structure's inside, having direct contact with it. According to the intention of its designers, Hyperbody should be compatible with premises of the new architectural triad, which is not any more: Function - Construction - Form, but Game - Set Match. Game means that architecture is becoming a game, played in the space of Hyperbody. Set derives from setting the space parameters by users, which is the result of the game, and Match - matching to new conditions. It means that the designed space is fully programmable to systematically meet requirements and needs of a user (Zalewski, 2007).

Thanks to these new technologies the future of architectural designing may present in the following way. Computer - a creator, thanks to entering suitable data, e.g. area of a facility, cubature, functions, a number and "kind" of users, construction materials, roof inclinations, type of elevation, maximum costs etc. it will design in a virtual way and will present a ready, objectively correct project to an investor. It may imply that the role of an architect will be limited to collecting documents and signing them.

Common application of programmes based on information technology as an environment and a tool used for validation of correctness of functional, ergonomic and aesthetic solutions in architectural designing is, as it seems, a question of the near future. Visualization of a facility before it is erected is particularly interesting for persons who lack spatial imagination or who do not want to learn the details of a technical drawing. Such future is also fascinating from the point of view of conceptual work - the programmes will enable a designer and future users to test a non-existent building in conditions very similar to real ones and they will also favour creative reinterpretation of the observed model and probably lead to unexpected discoveries.

Architectural software for work in virtual reality may also develop in two directions. The first one is desired by designers. It would support avoiding errors which cause user's discomfort, and on the other hand, it would enable to present solutions to an investor in the way understandable for him. Another direction is less optimistic for a designer. However, it is justified to think that in the near future an investor will be able, by means of a suitable computer programme, to generate a building meeting his requirements, not asking an architect for his opinion (Ujma-Wąsowicz \& Gil, 2005).

\section{Can a disabled person be protected from isolation?}

Earlier the only directions of activities in the area of improvement of quality of life of disabled people was elimination of architectural barriers. This process with better or worse results is carried out in required by law architectural and construction documents as well as in the phase of activities correcting the existing state (Ujma-Wąsowicz, 1996). It turns out that limiting oneself only to making architectural space available is insufficient. A greater challenge is eliminating psychological barriers, which have exogenous or endogenous background.

How can a disabled person get out of proverbial 'four walls'? Communication of the disabled with the outer world is a task which is often difficult to realize. Fortunately, in the 
era of the Internet it does not have to mean the necessity of getting out of a flat. It is just the strength of the Internet. It is enough to express one's reflections on the computer monitor and they will trigger off discussions. It is not a problem that during a discussion for example about literature a person expressing very interesting opinions does not walk or hear. In the same way as in the real world, also on the Web it is important not to limit oneself to four walls. It is the fact that the Internet is ideal for supporting different abilities of members of the Internet community. Contacting the disabled with other users of the Web encourages to take up new challenges and turns attention to some issues they would not care about otherwise. The possibility of sharing their, often exceptional knowledge with others is equally important for disabled people, they create their own Internet sites, blogs or participate in different Internet forums (Kowalczyk, 2006).

Paradoxically, from one isolation being often nobody's fault they move to so called secondary isolation, which is the subject of these reflections. The problem requires undertaking research concerning reasons for existence of this phenomenon in the mentioned environment as well as the methods of its active reduction. Obviously, it is dependent on a kind of a disability and orders given by doctors and physiotherapists.
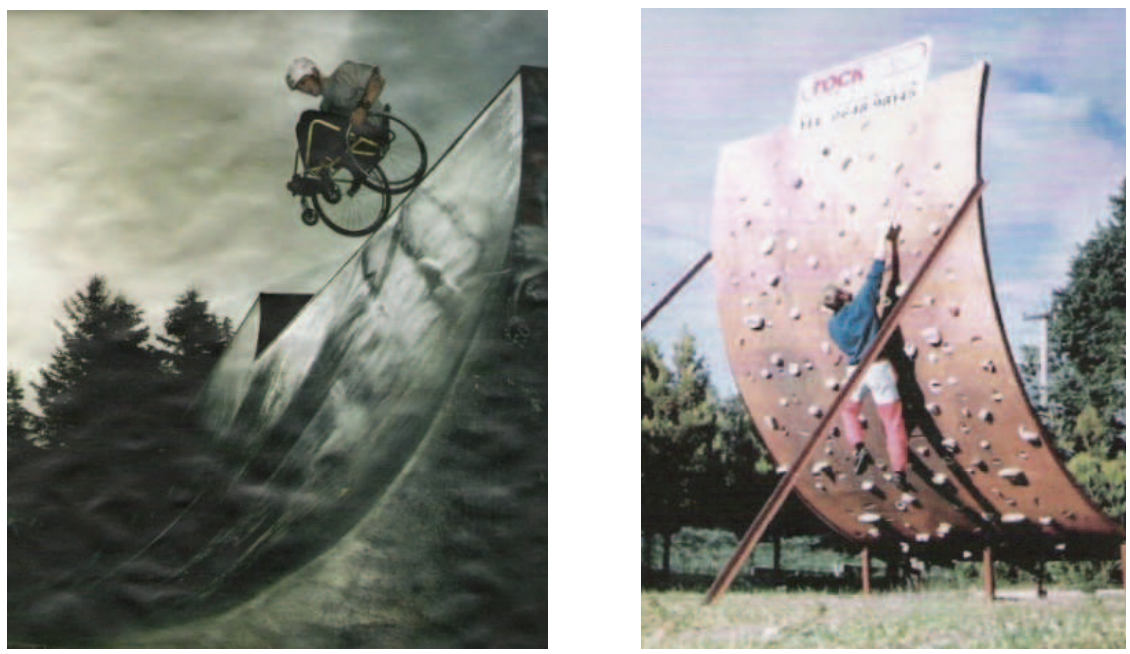

Photo 2. Extreme sports practised by the disabled

People who suffer from irreversible changes of some organs, but whose other organs function correctly, can be helped by intensive training, which can contribute to improvement of activity of the healthy organs and compensate for the lost functions. In order to achieve the best possible physical fitness of healthy organs it is essential to practise a properly selected sport discipline, even on the competitive level. Among the disciplines which improve physical fitness swimming should be mentioned on the first place. For people with dysfunctions of lower limbs but whose upper limbs function correctly, who use a wheelchair to move, among others the following sport disciplines are recommended: discus throw, putting the shot, javelin throw, archery, basketball (in a sitting position on a wheelchair) and others. Running and jumping are sport disciplines advised for people with dysfunction of upper limbs, whose lower limbs function correctly. Practising canoeing and sailing is available and recommended for people with different dysfunctions of motor 
organs, even with amputated upper limbs, thanks to using appropriate prostheses. These sports activities develop general physical fitness and are very beneficial for the psychological condition, giving a lot of satisfaction and pleasure. For the blind or for people with hearing disorders it is possible to practise a lot of sport disciplines with properly adapted rules. Winter sports, such as skiing and ice skating are advisable for people with preserved, different fitness of upper and lower limbs (Milanowska, 1997). Also practising extreme sports is popular, independently of a degree of disability (Photo 2.) (UjmaWąsowicz, 2007a).

It is possible to state, that interactive reduction of the threat of isolation caused by using electronic devices e.g. a computer, enters the area of active rehabilitation. Better fitness and physical condition achieved by the disabled is very beneficial for their psyche and social behaviours. It gives them self-esteem, encourages to take up a job, a professional training or to change a profession. These factors are essential because they positively influence social integration of the disabled in their environment.

\section{Final remarks}

- Growing meaning of knowledge and new economy of global society requires access to information and we can't withdraw from using more and more advanced information technologies, computer technics and electronic tools.

- The research of isolation risk among students caused by using computers digital devices in free time confirmed the thesis that users of computers, iPAQs or DVD devices are not aware of this risk. However, instinctively they feel that active recreation and team games are the methods which help not only to relax but also to reduce the effect of isolation.

- The subsequent conducted research proved that the problem of isolation among school children does not exist. It is natural for them to spend time in a group. In the same time, being asked a question concerning the possibility of practising sport disciplines with the disabled, $90 \%$ of young people are for integration, which may take different forms;

- The comparison of conducted research allows to confirm the thesis that isolation starts to be a threat when a man takes on particular social roles and has to decide about his life and many a time about life of other people

- In spite of rich sports base, a problem is a limited inclination of students for regular and also spontaneous practicing sport. One of essential reasons of such a situation is neglect in the period of bringing up a young man, because in this time follows a process of transformation exuberant willingness to spend free time in active way into a habit. The habit, which later appears to be very desirable.

- Widening educational market in Poland will require a transition from learning methods 'face-to-face' to methods 'e-learning', in which isolation will be not only a threat but also a social problem. While reducing intellectual effort and treating work with a computer as a reduction of emotional effort, such a situation may be a reason of degeneration of interpersonal communication, indispensable for team work.

- The research concerning a threat of isolation caused by work with a computer in free time, confirmed assumptions of the authors that students cannot manage health risk, connected with hygiene of studying and of working. 
- It is necessary to work out new planning and design giudelines for implementation of outdoor sports facilities in urbanized environment, matching the expectations of different groups of users and current technological development. These facilities, because of their locations and realized functions, are important elements of composition of urban space. Therefore, the state policy should be oriented on investing in commonly accessible outdoor sport areas, according to the latest trends.

- The authors of the article are academic teachers and have opportunities to encourage for discussion on these issues the student environment, which also includes disabled persons. The discussions prove the usefulness of the begun research and indicate the need of its expansion into the environments of the disabled, working people and senior citizens, it means creating a map of isolation and methods of its reduction for particular environment and professional groups.

\section{References}

Bonstingl J.J. (1999). Quality School. Introduction to Total Quality Management in Education. Pub.: CODN (Centralny Ośrodek Doskonalenia Nauczycieli), ISBN 83-85910-23-9, Warsaw, Poland

Charlton S.G. (2002). Questioner Techniques for Test and Evaluation, In: Handbook of Human Factor Testing and Evaluation. Charlton, S.G. \& O'Brien T.G., pp. 225-231, Lawrence Erlbaum Associates Publishers, ISBN 0-8058-3290-4 - ISBN 0-8058-3291-2 Mahwah, New Jersey, London

Damasio A.R. (2000). The Feeling of What Happens. Pub.: Dom Wydawniczy Rebis, ISBN 8373-01-001-7, Poznań, Poland

Goleman D. (1997). Emotional Intelligence. Pub. Media Rodzina of Poznań, ISBN 83-85594-469, Poznań, Poland

Kiergegaard S. (1995): The Sickness unto Death (Sygdommen til doden). Pub. Zysk i S-ka Wydawnictwo s.c., ISBN 83-86530-87-1, Poznań, Poland

Karwowska A. (2008). Zakompleksieni i nieufni, Daily News METRO

Kondziela J.J. (1986): A Person in Community. Social ethic, economic and international problems. Pub.: Księgarnia św. Jacka, Imprimatur, Janusz Zimniak, Bp VI-1637/86, Katowice, Poland

Kowalczyk A. (2006): Wyjść z czterech ścian. Journal Integration. Magazyn dla niepetnosprawnych, ich rodzin i przyjaciót. (1/2006) 54-55, ISSN 1232-8510

Milanowska K. (1997): The importance of increased loco motor activity for disabled people as a compensating factor of their psychophysical efficiency. Sport - Chance for Disabled, pp. 259-260, ISBN 83-87252-0304, Pub. Polish Association of Disabled People Central Committee in Cracow, Poland

Musioł T. (2003): The State Ergonomics Consciousness Employed a Like Index the Quality Safety of Organisation. Proceedings of Human-Computer-Interaction, pp.1401-1405, ISBN 0-8058-49-31-9, Crete, Greece, June 2003. Lawrence Erlbaum Associates, Publishers, Mahwah, New Jersey, London

Musioł T. \& Ligarski M. (2004): A didactic measure of quality of work safety management classes - case study. Proceedings of Dilemmas and Issues of Modern Ergonomics and Work Safety Education and Researches pp. 209-214, ISBN 83-906191-4-8, Poznań, 2004, Pub. By Poznan University of Technology, Poznań, Poland 
Musioł T. (2004). Organization as a Phenomenon. Proceedings of Czy dwie kultury?, pp. 267270, ISBN 83-913835-5-5, Joint The Society for Development of Polish Science, Zabrze, Poland

Musioł T. (2005a) Ergonomical aspect of disabled people education at Faculty of Organisation and Management of Silesian University of Technology. Zastosowania Ergonomii, Vol. No 1-3. 2005, pp. 181-188, ISSN 1232-7573

Musioł T. (2005b). The State of Ergonomics Consciousness of Participants of Didactic Process in Individual Assessment. Proceedings of Human-Computer-Interaction, Vol. No 8, ISSN 1044-7318/ online ISSN 1532-7590, Las Vegas USA, June 2005r. ,Mira Digital Publishing

Musioł T. (2007). Próba identyfikacji zagrożeń organizacji w warunkach globalizacji. Proceedings of Rozwój i funkcjonowanie przedsiębiorstw w warunkach globalnej gospodarki światowej pp. 101-106. ISBN 978-83-87296-23-0, Pub. Agencja Artystyczna PARA, Katowice

Musioł T. \& Ujma-Wąsowicz K. (2007) Identification of Threat of Isolation as a Result of Work with a Computer In Free Time, Proceedings of Human-Computer-Interaction, pp.707-715, ISBN 978-3-540-73282-2, Springer Pub., Heilderberg, Gemany

Stein, E. (1998). About empathy problem. Doctorate dissertation

Ujma-Wąsowicz, K. (1996). Gliwice Przyjazne Osobom Niepełnosprawnym. The programme of adaptation the city of Gliwice for disabled people. The Report prepared by K. UjmaWasowicz, M. Wegrzyn, S. Zemta. Silesian University of Technology, Gliwice, Poland

Ujma-Wąsowicz, K. (2005). Outdoor Sport in the City. Development Trends. Czasopismo Techniczne, series of Architecture part 2, Vol. No 9-A/2005, pp. 312, ISSN 0011-4561

Ujma-Wąsowicz K, Gil A.: (2005) Ergonomics and Architecture. Designing in Virtual Reality. Future or Choice?, Proceedings of Human-Computer-Interaction, Vol. Posters ISSN 1044-7318/ online ISSN 1532-7590, Las Vegas USA, June 2005r. ,Mira Digital Publishing

Ujma-Wąsowicz K. (2007a): Ergonomiczne czynniki jakości środowiska aktywnej rekreacji. Zastosowania Ergonomii, Vol. No 1-2. pp. 235-244, ISSN 1232-7573

Ujma-Wąsowicz K. (2007b): Outdoor places of active recreationin urbanized areas. Development targets and directions. Czasopismo Techniczne, series of Architecture Vol. No 1-A/2007 pp. 169-174, ISSN 0011-4561, ISSN 18976271

Ujma-Wąsowicz K., Musioł T. (2008) Outdoor sport in the city of the future: planning and designing issues, Proc. of the 5th Int. Conf. on The Sustainable City, pp. 13-22, eds. C.A. Brebbia, A. Gospodini \& E. Tiezzi, WIT Press, Southampton, UK,

Zalewski K. (2007). Cybrids: Hybrids of Psyhical Space and Cyberspace. Cyberspace, Architecture E Urban serie 1/2007, pp.23-30, Published with permission of the President of the Silesian University of Technology, Gliwice 


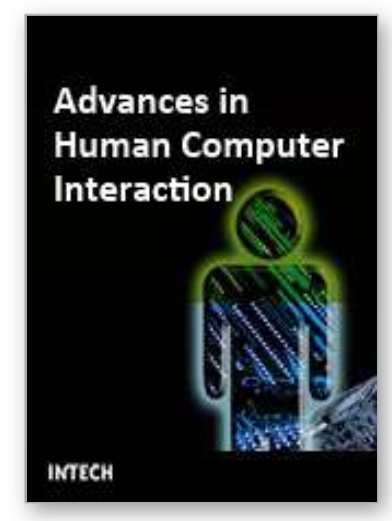

\section{Advances in Human Computer Interaction \\ Edited by Shane Pinder}

ISBN 978-953-7619-15-2

Hard cover, 600 pages

Publisher InTech

Published online 01, October, 2008

Published in print edition October, 2008

In these 34 chapters, we survey the broad disciplines that loosely inhabit the study and practice of humancomputer interaction. Our authors are passionate advocates of innovative applications, novel approaches, and modern advances in this exciting and developing field. It is our wish that the reader consider not only what our authors have written and the experimentation they have described, but also the examples they have set.

\section{How to reference}

In order to correctly reference this scholarly work, feel free to copy and paste the following:

Teresa Musiol and Katarzyna Ujma-Wasowicz (2008). The Method of Interactive Reduction of Threat of Isolation in the Contemporary Human Environment, Advances in Human Computer Interaction, Shane Pinder (Ed.), ISBN: 978-953-7619-15-2, InTech, Available from:

http://www.intechopen.com/books/advances_in_human_computer_interaction/the_method_of_interactive_red uction_of_threat_of_isolation_in_the_contemporary_human_environment

\section{INTECH}

open science | open minds

\section{InTech Europe}

University Campus STeP Ri

Slavka Krautzeka 83/A

51000 Rijeka, Croatia

Phone: +385 (51) 770447

Fax: +385 (51) 686166

www.intechopen.com

\section{InTech China}

Unit 405, Office Block, Hotel Equatorial Shanghai

No.65, Yan An Road (West), Shanghai, 200040, China

中国上海市延安西路65号上海国际贵都大饭店办公楼 405 单元

Phone: +86-21-62489820

Fax: +86-21-62489821 
(C) 2008 The Author(s). Licensee IntechOpen. This chapter is distributed under the terms of the Creative Commons Attribution-NonCommercialShareAlike-3.0 License, which permits use, distribution and reproduction for non-commercial purposes, provided the original is properly cited and derivative works building on this content are distributed under the same license. 